\title{
Surto de intoxicação por Sida carpinifolia associada à parasitose por Eurytrema sp. em um rebanho de caprinos em Palmeira/PR
}

Ana Paula Brenner Busch Becker[a]", Camilla Maciel de Souza ${ }^{[b]}$, Bruna Lampe Zielinski[a], Ana Paula Rossa ${ }^{[a]}$, Luíza Costa Barcellos ${ }^{[a]}$, João Batista Poncio da Silva ${ }^{[a]}$, Daniel Carlos Coatti Rocha ${ }^{[a]}$, Luciana Machado da Silva ${ }^{[a]}$, Renato Silva de Sousa ${ }^{[a]}$

\footnotetext{
[a] Universidade Federal do Paraná (UFPR), Curitiba, PR, Brasil

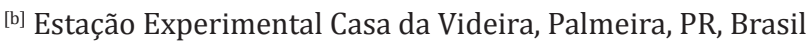

*Autor correspondente

e-mail: apbbusch@yahoo.com.br

\section{Resumo}

O Eurytrema sp. é um trematódeo heteroxeno que parasita vertebrados, sendo sua principal localização nos ductos pancreáticos, mas também pode parasitar os ductos biliares e intestino. São dois os hospedeiros intermediários: o primeiro representado pelo caramujo terrestre do gênero Bradybaena e o segundo por gafanhotos do gênero Conocephalus. A maioria dos casos é subclínico e os animais acometidos podem apresentar sinais de doença debilitante, podendo acarretar em pancreatite e obstrução do ducto pancreático. A Sida carpinifolia, conhecida popularmente como guanxuma, possui potencial tóxico devido à presença do alcalóide indolizidina [a],2,8-triol, denominado swansonina, que inibe enzimas presentes no aparelho de Golgi. A ingestão frequente desta planta provoca sinais neurológicos, incluindo incoordenação, dismetria, hiperestesia, tremores musculares, quedas, depressão e emagrecimento, podendo também provocar diminuição da fertilidade e aborto. Este relato descreve um surto de intoxicação por Sida carpinifolia associada à parasitose por Eurytrema sp. em um rebanho de 39 caprinos das raças Toggenburg, Saanen e SRD, em uma propriedade localizada no município de Palmeira, Paraná. A queixa principal do proprietário foi: óbitos (3), caquexia e incoordenação (1). A propriedade foi acompanhada por 8 meses e, nesse período, $59 \%$ (23/39) dos animais apresentaram emagrecimento progressivo e sinais neurológicos (hiperestesia e dismetria de membros, tremor de intenção, dificuldade de levantar e se manter em estação ao se alimentar), opacidade de córnea e feridas de decúbito, variando em suas combinações e intensidades. Ocorreram abortos (15\%; 6/39) e um natimorto (3\%;1/39). No período, houve óbitos (15\%;6/39) e eutanásias (36\%;14/39), pois os animais não respondiam ao tratamento de suporte e correções no manejo. Na necropsia de 10 animais, observaram-se alterações macroscópicas no pâncreas, como coloração esbranquiçada, tamanho diminuído e consistência firme. Ao exame microscópico, observaram-se ácinos atrofiados envoltos por 
espessa camada de tecido fibro-colagenoso associado a infiltrado linfoplasmocitário discreto multifocal. Nos ductos pancreáticos observaram-se larvas compatíveis com Eurytrema sp. No encéfalo não foram observadas alterações macroscópicas, porém na microscopia notou-se células de Purkinje discretamente vacuolizadas com tumefação e citoplasma hipereosinofílico; lesões compatíveis com intoxicação por guanxuma. Em todos os animais necropsiados, constataram-se os mesmos achados, variando em intensidade. As manifestações clínicas, tanto da euritrematose quanto da intoxicação por guanxuma, foram agravadas pela associação destas doenças, sendo que cada uma isoladamente possivelmente não teria provocado tal caquexia a ponto da não recuperação do animal e grande perda do plantel. 0 diagnóstico foi realizado pela observação de S. carpinifolia na propriedade, sinais clínicos e achados de necropsia e histopatologia. Não há tratamento eficaz para nenhuma das doenças relatadas, e pelo fato de provocarem perdas econômicas representadas por óbitos, queda na produção e gastos inerentes às tentativas de tratamento e exames diagnósticos, ressalta-se a importância da prevenção através do controle de plantas invasoras nas pastagens e manejo nutricional adequado. 